\title{
The Implementation of Core Learning Model (Connecting, Organizing, Reflecting, Extending) on the Bank and Financial Institution Course Based on Industrial Revolution 4.0
}

\author{
Menik Kurnia Siwi ${ }^{1}$, Jean Elikal Marna ${ }^{2}$ \\ ${ }^{1}$ Universitas Negeri Padang, Padang, Indonesia, $\bowtie$ menikkurnia@gmail.com \\ ${ }_{2}^{2}$ Universitas Negeri Padang, Padang, Indonesia, $\bowtie$ jeanelikalmarna@gmail.com
}

\begin{abstract}
This study aims to apply the CORE learning model (connecting, organizing, reflecting, extending) to the subjects of banks and financial institutions based on industrial revolution 4.0. This research uses research and development (R \& D) methods. This model development model uses the IDI model (Instructional Development Institute). The IDI model establishes the principles of a system approach which includes three stages, namely define, develop, and evaluate (Grabowski, 2003: 3). Based on the explanation on this learning innovation report, it can be concluded that: 1) Learning innovations in Bank and Financial Institution Course with CORE learning models produced by RPS, SAP, Teaching Materials, Media and Learning Videos. 2) Learning innovations in the subjects of Banks and Financial Institutions with CORE learning models can improve communication skills, think critically and innovatively students.

Keywords: core learning model, IDI, instructional development institute
\end{abstract}

\section{Introduction}

Indonesia is a country that has the demographic bonus of the younger generation up to 2025. For this reason, the government must comprehensively prepare its young generation to face the industrial revolution 4.0. The young generation is the spearhead of the country's progress in facing the rapid progress of information and technology. The habit of using online media by the younger generation should be directed towards the positive. As many as $49.52 \%$ of internet users in the country are those aged 19-34. Furthermore, according to the Association of Internet Service Providers in Indonesia (APJII) the majority of internet users $72.41 \%$ are still from the urban community. Its utilization has gone further, not only for communication but also buying goods, ordering transportation to do business and work.

Revolution Industry 4.0 is an industry that combines automation technology with cyber technology. This is a trend of data automation and exchange in manufacturing technology. Includes physical cyber systems, internet of things (IoT), cloud computing and cognitive computing. Industry 4.0 produces smart factories. With the existence of intelligent devices that are always connected via the internet, it provides convenience in accessing data and increasing the efficiency of time, effort and cost.

In addition to the manufacturing industry the use of the internet or known as the digital era has also penetrated into the business world known as e commerce and e business (electronic commerce) and in Indonesia known as the startup business that is more directed to online businesses that are made and loved by generations millennial. As a businessman and e-commerce user or online business, the payment system is very important. The main thing that underlies the difference between online business and offline business is face to face, so the payment system that requires must be done online too (virtual currency). Luckily all transactions in the digital world have been made easier because there are many ecommerce payment systems with different features and functions. Even so, according to research conducted by the Indonesian research company MARS in collaboration with Indonesian E-commerce associations (IdEA) in 2016 stated that $14.6 \%$ of participants or the younger generation were still reluctant to do online shopping because of dizzying transactions. 
Facing the reality above, Education in Indonesia should prepare its young generation to face the industrial revolution 4.0. Education must be involved in the utilization and regulation of online transaction services because the ease of access to information at this time is like two blades which can provide positive benefits or effects and can also have a negative effect. Higher education is the level of education that is most likely to be able to develop and make use of all the technological and information acceleration towards promising.

Universitas Negeri Padang is one of the best universities in West Sumatra. Universitas Negeri Padang has two fields in printing its graduates, namely the education field that prints prospective and non-educational candidates who print prospective workers outside the world of Education. As a printer for prospective teachers indirectly the future of Indonesia's young generation is in the hands of students of future teacher candidates. Therefore the provision of sufficient provisions related to the development of technology and information is currently very useful not only for students but also for the younger generation of Indonesia at a younger level.

To deliver and provide information regarding the world of banking and financial traffic and payment systems for the Department of Economic Education, economic Faculty of Universitas negeri Padang, as lecturers for educational students / future economic teacher candidates prepare one of the subjects related to this subject which is named the subject of Banks and Financial Institutions. In this course, it is given in full related to the utilization of the banking world in the economy. However, so far the discussion of this subject is still conventional and the explanation of the financial system is still offline or directly

Seeing the reality needed in the field related to the knowledge of online business with all payment systems, a learning model that is appropriate and can accommodate the needs of students is needed. One of the appropriate learning models is the CORE learning model which is the development of a learning model of problem based learning and constructivism. CORE is an acronym for connecting, organizing, reflecting and extending. This learning model is a learning model that invites students to think deeply. The syntax is $(\mathrm{C})$ the connection connects the new concept with the old concept or between concepts, $(\mathrm{O})$ the organization of ideas to understand the material, (R) rethink, explore, and explore, (E) develop, expand, use and find. The selection of this learning model will be carried out in the local lectures, for example related to the subject of online payment systems (virtual currency), then what students will do is (C) linking and analyzing payment systems both offline and online, $(\mathrm{O})$ organizing the use and use of each each payment system, $(R)$ rethink which payment system is better and look for information from all sources such as from Bank Indonesia (E) Develop and use or even create software or webmoney for online payments in e commerce and e business. By implementing this syntax, it is expected that students can think more critically and be able to produce an online product and also be able to convey to their students in the future and be able to provide more benefits to online business users. Therefore the learning innovation grant team is interested and intends to develop learning innovations with the title "Application of the CORE learning model (connecting, organizing, reflecting, extending) to the Subjects of Banks and Financial Institutions".

\section{Methods}

This research uses research and development ( $R$ \& D) methods. This model development model uses the IDI model (Instructional Development Institute). The IDI model establishes the principles of a system approach which includes three stages, namely define, develop, and evaluate (Grabowski, 2003: 3). The first stage is the define stage that contains steps to identify problems, analyze curriculum, analyze student characteristics, analyze concepts / learning material. The second stage is development which contains the preparation of the initial form (prototype) of the product and product validation. The third 
stage is the evaluate stage which contains the steps of the trial and analysis of the results of the trial. The development can be seen from the picture below,

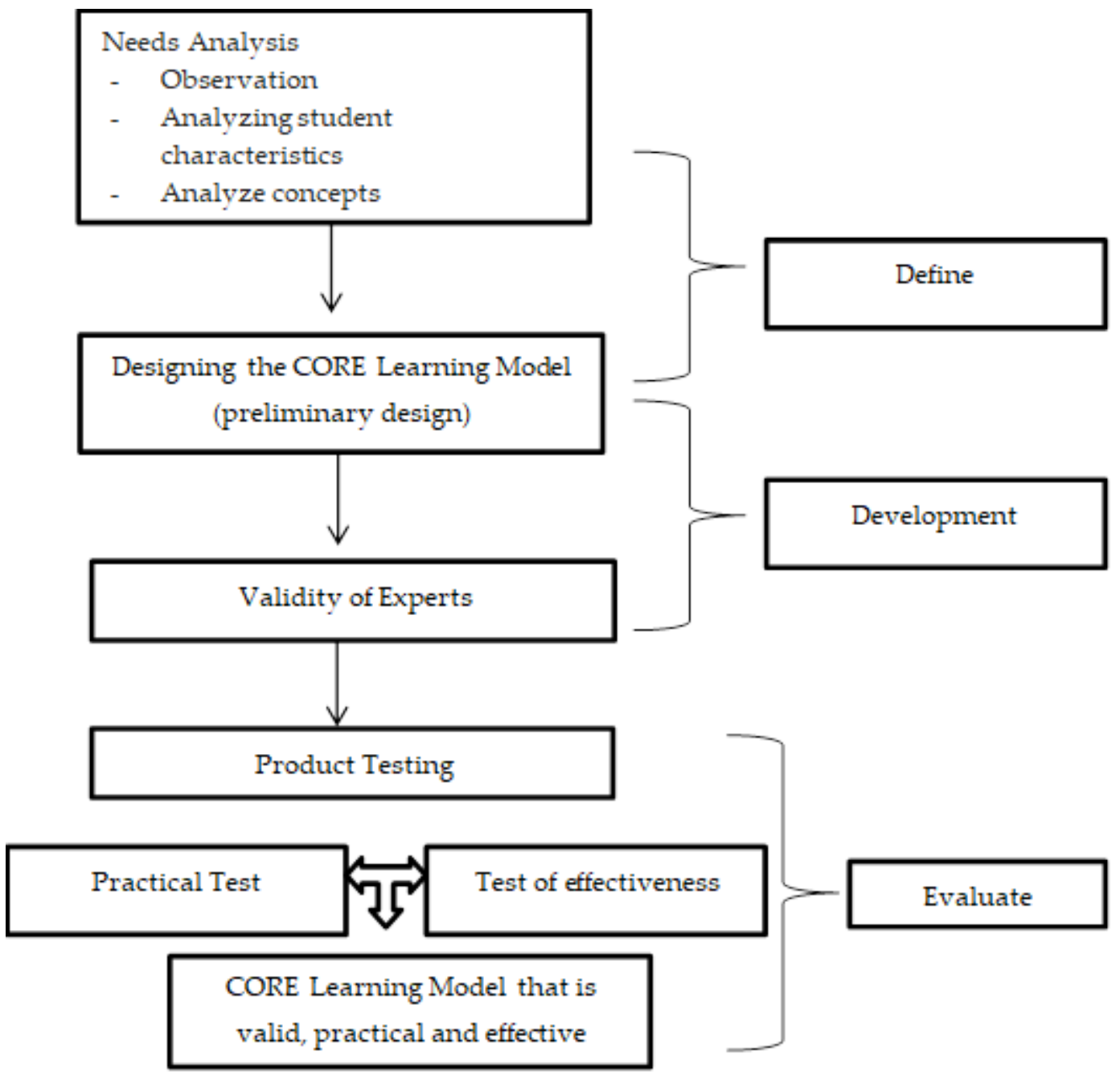

Figure 1 Design of CORE Learning Model Development

\section{Development of Learning Innovation}

This study produced a product of the CORE learning model in the subjects of Banks and Financial Institutions. The process is as follows:

\section{Define}

This research and information gathering is the initial stage in developing the CORE learning model. At this stage of the needs analysis of the CORE learning model, several analyzes were carried out including, setting Lecture Plans, semester Learning Plan analysis of subject matter, and student characteristics

\section{Establish lecture plans}

The defining stage is done by setting Lecture Plans which refers to the semester learning plan of the Bank and financial Institution courses that use the CORE learning model. The meeting material four and five, namely: designing, developing and evaluating learning media.

Material Settings 
CORE learning models needed, researchers formulate the main concepts that are developed systematically and identify and support concepts and concepts that are relevant and related to materials. Designing, developing and evaluating media learning. The main concepts in designing, developing and evaluating learning media are:

1. Designing Media: Design learning media with the Assure Model approach and Design learning media with the Anderson Model

2. Developing the Media: Develop audio learning media, Developing visual learning media, Developing graphic learning media

3. Evaluating the Media: The importance of media evaluation andComponents of Media evaluation Student Analysis

Student analysis is conducted to see and know the characteristics and environment of students at the Bank and Financial Institution Courses in the section code 201810530082 totaling 35 students.

\section{Development}

This stage is done by determining the concept of the CORE learning model that will be built. The product sketch is made based on the defining stage that has been done, then determining the media object that will be used in developing the CORE learning model.

\section{Evaluate}

Practical test data for the CORE learning model on bank and financial institution courses taken from questionnaires that have been distributed to lecturers and students. Effectiveness Test Data, Student learning outcomes were taken at the pretest before applying the CORE learning model compared to the posttest learning outcomes after applying the CORE learning model.

\section{Result and Discussion}

The learning model is a conceptual framework that describes a systematic procedure in organizing learning experiences to achieve certain learning goals, which serves as a guide for learning designers and instructors in designing and implementing learning activities, Wahyu Widada (Dewi Herawaty, 2009)

Calfee et al. also revealed that what is meant by CORE model learning is a learning model that expects students to be able to construct their own knowledge by connecting (organizing) and organizing (organizing) new knowledge with old knowledge then rethinking the concept being studied (Reflecting) and students are expected to expand their knowledge during the teaching and learning process takes place (Extending) (Calfee et all, 2004: 222

\section{The process of developing models}

The process of developing models and learning tools is by conducting trials with three stages including expert testing, limited empirical testing and field testing which begins with the initial investigation phase, and the design phase

\section{Initial investigation of the learning model}

The learning model developed is a learning model that requires students to play an active role in lectures and based on the phenomenon of industrial revolution 4.0. the learning model was developed based on the results of initial investigations conducted on lecturers, students and the syllabus used

Table 1 The Results of The Initial Investigation of The Learning Model

\begin{tabular}{lcll}
\hline Numb. & Type & & \multicolumn{1}{c}{ Result } \\
\hline 1 & Students & - & Students are still involved less actively in class \\
& & - & Students have smartphones that have not been optimized \\
& & Students are less motivated in class \\
\hline 2 & Lecturer & - & The teaching and learning process is more discussion and \\
& & group presentations \\
& & & Interaction between students and lecturers is still lacking \\
\hline
\end{tabular}


Table Cont...

\begin{tabular}{|c|c|c|}
\hline & & $\begin{array}{ll}\text { - } & \begin{array}{l}\text { Lecturers do not use applications that support technology in } \\
\text { learning }\end{array} \\
\end{array}$ \\
\hline 3 & $\begin{array}{l}\text { Curriculum / } \\
\text { syllabus }\end{array}$ & 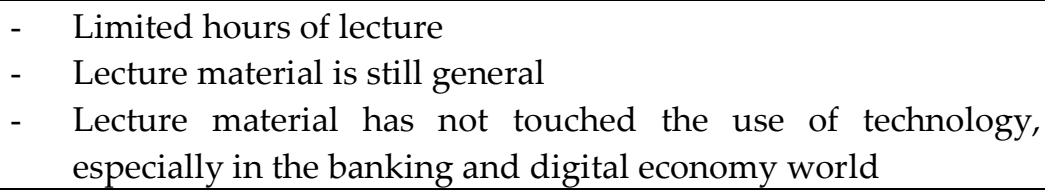 \\
\hline 4 & $\begin{array}{l}\text { Carrying } \\
\text { capacity }\end{array}$ & $\begin{array}{ll}\text { - } & \text { Campus wifi is always on } \\
\text { - } & \text { Facilities in the classroom are adequate }\end{array}$ \\
\hline
\end{tabular}

With the initial investigation it can be seen that so far students have not been optimally involved in the classroom. The lecturer only requires students to make presentations and group discussions. The acceleration of technology has not been utilized optimally in the classroom.

\section{Initial Investigation of Lesson Plan}

In the initial investigation activities related to lesson plan, they include (1) demands for progress and technology in the classroom (2) The conditions of students include student activities in learning and use of technology, (3) conditions of lecturers who should be more applicable to technology and (4) lecture syllabus that still needs to be updated again

Details of activities in the initial investigation of the development of lesson plan can be seen in the following table.

Table 2 Initial Investigation Activities on the Development of Lesson plan

\begin{tabular}{lll} 
Numb. & \multicolumn{1}{c}{ Activity } & \multicolumn{1}{c}{ Result } \\
\hline 1 & Preliminary analysis & $\begin{array}{l}\text { Discuss with the lecturer team and study the material } \\
\text { needs and students needs according to the times }\end{array}$ \\
\hline 2 & Student analysis & $\begin{array}{l}\text { Knowing student cognitive characteristics and } \\
\text { affective characteristics through theoretical studies } \\
\text { and observations during the lecture process }\end{array}$ \\
\hline 3 & Material analysis & $\begin{array}{l}\text { This model is designed to be used on every material } \\
\text { in a bank and financial institution course. This model } \\
\text { is expected to be able to accommodate material needs } \\
\text { and the application of technology that can be applied } \\
\text { in the classroom }\end{array}$ \\
\hline 4 & Concept Analysis & $\begin{array}{l}\text { Analyzing concepts about digital economy and } \\
\text { online payment systems and their applications in } \\
\text { learning which are new concepts that need to be } \\
\text { introduced to students }\end{array}$ \\
& & $\begin{array}{l}\text { Formulate tasks that will be carried out by students } \\
\text { during learning activities both individually and in } \\
\text { groups }\end{array}$ \\
\hline 5 & Task Analysis & Formulating indicators of student learning outcomes \\
& on digital economic material and payment systems \\
\hline 6 & Formulation of learning & Choosing the right media for presenting lecture \\
& objectives & material and the media chosen are Power Point \\
& Presentation and illustration videos \\
\hline 7 & Fedia selection & $\begin{array}{l}\text { Devices developed in the form of syllabus, learning } \\
\text { Plan and teaching material }\end{array}$ \\
& &
\end{tabular}


Table Cont...

\begin{tabular}{lll}
\hline 9 & Initial design & $\begin{array}{l}\text { Making lesson plan for banks and financial } \\
\text { institutions in the form of syllabus, sap and teaching } \\
\text { materials }\end{array}$ \\
\hline 10 & $\begin{array}{l}\text { Validity / testing of experts } \\
\text { and practitioners }\end{array}$ & $\begin{array}{l}\text { To know the validity of the validators the researcher } \\
\text { developed an assessment questionnaire on the initial } \\
\text { design of the model }\end{array}$ \\
\hline 11 & Revision of validation & $\begin{array}{l}\text { Make improvements to the learning device in the } \\
\text { initial design }\end{array}$ \\
\hline 12 & Simulation & $\begin{array}{l}\text { Check the implementation of lesson plan in } \\
\text { accordance with the time set }\end{array}$ \\
\hline 13 & Limited trial & $\begin{array}{l}\text { Test devices on students who take the courses of } \\
\text { banks and financial institutions }\end{array}$ \\
\hline 14 & Learning E revision & $\begin{array}{l}\text { Revise the device based on the results of a limited } \\
\text { trial. }\end{array}$ \\
\hline
\end{tabular}

\section{Learning Syntax with Innovation}

There are four learning Syntax with CORE model, Connecting (connecting old information with new information or between concepts), Organizing (organizing the information obtained), Reflecting (rethinking information that has been obtained), Extending (expanding knowledge).

1. In the beginning of the course the lecturer shows something unique that is trending, or shows footage of the film that is currently warm in the community or what kind of activity is the point where the lecturer opens learning with something unique, where the uniqueness has hidden meaning. There are things that the lecturer will later draw on the introduction of the material to be discussed.

2. The connecting process begins with the lecturer questioning past learning concepts.

3. Organizing is done by the way the lecturer asks the opinions or ideas that students have on the concepts to be learned.

4. After the presentation of the lesson material has been completed, the next step the teacher divides students into small groups. The small group then discusses the discussion critically about what has been learned.

5. At this stage reflecting begins, students in the group rethink, explore, dig deeper into information through group learning.

6. While at the extending stage, students are given individual assignments to expand, develop and use an understanding of the material that has been learned.

\section{Validation of Practicality Tests, and Product Effectiveness of Innovation Validity Test}

Collecting data on the validity of the CORE learning model as a learning model is by using a questionnaire, In this case the researcher gave a questionnaire to 2 validators who would validate the CORE learning model developed. 
Table 3 Results of Material Validation on SAP CORE Learning Model

\begin{tabular}{cccl}
\hline Numb. & Validator & Validity Test Results & Category \\
\hline 1 & Validator 1 & 92.94 & Valid \\
\hline 2 & Validator 2 & 95,29 & Valid \\
\hline
\end{tabular}

From table 3 can be seen from the results of validator 1 and validator 2 which are 92.94 and 95.29 with an average of 94.115 with a valid category. From table 4.3 it can be seen that validation of the CORE learning model is valid so that it can be concluded that the CORE learning model is in the "valid" category.

\section{Evaluate}

\section{Practicality Test Data}

Practical test data for the CORE learning model in Bank and Financial Institution courses taken from questionnaires that have been distributed to lecturers and students.

\section{Practicality Test Data Based on Pact / Lecturer Response}

Practicality is related to the ease of use of the CORE learning model developed. Practical data was obtained through a questionnaire filled by two practitioners. Based on the questionnaire contents, it can be seen the practicality of the CORE learning model. The results of the assessment of the practicality of the CORE learning model are summarized in table 4 following.

Table 4 Practicality Result Data of CORE learning model according to Lecturer Response

\begin{tabular}{lllcccc}
\hline \multirow{2}{*}{ Numb. } & \multirow{2}{*}{$\begin{array}{c}\text { Aspects of } \\
\text { Assessment }\end{array}$} & P1 & P2 & Avercentage Assessment & \multirow{2}{*}{ Category } \\
\cline { 3 - 6 } & Technical & 92 & 100 & 96 & very practical \\
\hline 1 & Content & 96 & 96 & 96 & very practical \\
\hline 2 & Design & 92 & 94 & 93 & very practical \\
\hline 3 & Average & & 95,15 & very practical \\
\hline
\end{tabular}

P1 = Practitioner Number 1, P2 = Practitioner Number 2

The overall average is $95.15 \%$ with a very practical category. These results indicate that the CORE learning model developed facilitates lecturers in helping students learn independently and helps lecturers in understanding the concepts of learning materials based on industrial revolution 4.0

Practicality Test Data Based on Student Response

Table 5 Practicality Result Data of CORE learning model according to Student Response

\begin{tabular}{clcc}
\hline Numb. & Aspects of Assessment & Percentage Assessment & Category \\
\hline 1 & Convenience & 84,3 & very practical \\
\hline 2 & Motivation & 84,5 & very practical \\
\hline 3 & Attractiveness & 86,2 & very practical \\
\hline 4 & Usefulness & 88,5 & very practical \\
\hline & Average & 85,88 & very practical \\
\hline
\end{tabular}

\section{Effectiveness Test Data}

\section{Student learning outcomes}

Student learning outcomes are seen from the gain score difference at the pretest and posttest at the Bank and financial institution subjects. Learning outcomes in 35 students of bank and financial institution 
subjects obtained higher posttest results compared to the pretest.

\section{Data Analysis \\ Validation Analysis}

Table 6 Improving Learning Outcomes

\begin{tabular}{ll}
\hline & Learning Outcome Average \\
\hline Pretest & 75.5 \\
\hline Postest & 87 \\
\hline Capital gain Score & 11,5 \\
\hline
\end{tabular}

The draft instrument given to the validator is a valid draft. Validator consists of 2 lecturers from Economic Education Department to assess the material in the CORE learning model. The material assessment results can be obtained from the validator $1=92.9$ and for validator 2 at 95.6 with an average of 93.63 then categorized as valid, for the results of the design evaluation the validator 1 is 91.93 and for validator 2 is 93.5 with an average of 92.75 categorized as valid. And for the results of the assessment of language validator 1 for 85 and for validator 2 by 95 with an average of 90 categorized as valid. Then it can be concluded that interactive multimedia developed in terms of material and design is valid

\section{Practicality Analysis}

\section{Based on Lecturer Response}

The draft instrument given to practitioners is a valid draft. The practicality assessment of interactive multimedia is carried out by 2 economics education lecturers. The results of the practical assessment can be seen that there are three practical aspects of the CORE learning model based on the lecturers' responses through questionnaires. The average percentage is the assessment of the two practitioners, among others, (1) Technical usage obtained 96\%, (2) content obtained 96\%, (3) Design obtained 93\%, and obtained an overall average of $95.15 \%$ with very practical categories . so that it can be concluded that the practical CORE learning model is used by lecturers in carrying out the learning process.

\section{Based on Student Response}

The results of the Student response assessment can be seen in Appendix 15 based on Student responses to the ease of use of the CORE learning model obtained $84.3 \%$ with very practical categories, motivation aspects $84.5 \%$, attractiveness aspects obtained $86.2 \%$ with very practical categories, usefulness aspects obtained $88.5 \%$ with a very practical category and the overall average is $88.85 \%$ with a very practical category. It can be concluded that the practical CORE learning model is used by students in learning.

Based on the analysis of lecturers and students' responses to the practicality of the CORE learning model, it can be concluded that the CORE learning model developed is in a very practical category.

\section{Effectiveness Analysis}

Learning outcomes of the pretest (not using interactive multimedia) from 35 students obtained results (75.5), but the posttest learning results (using interactive multimedia) from 35 students obtained results for posttest (87) can be seen in table 4.5 and see the difference test two class averages can be seen in figure 4.12 , from figure 4.12 there is a significant price of 0,000 smaller than 0.05 so that it can be concluded that there is a significant difference between the results of the pretest and posttest

\section{Product Revision}

The main purpose of product revision is to improve the CORE learning model that has been designed so that it has the validity, practicality and effectiveness of the CORE learning model when used according to its needs. 


\section{Learning materials}

The learning material in the subject matter of Banks and financial institutions that is in the CORE learning model still has several disadvantages including governance writing, images that are not relevant to information.

As lecturers, they should always try to improve student learning outcomes. The efforts of lecturers to improve student learning outcomes are to use appropriate learning models and media, in the selection of models and media, careful thinking and preparation are needed. For this reason the learning model used must be student oriented. Because in the learning itself there is a lot of material that makes students confused and bored. Here students must practice to be able to solve problems.

Basically, individual are different. Similarly, in understanding the concepts that will be given. Therefore, learning is needed which helps students to master teaching material, so that learning completeness is achieved as expected. By using the CORE learning model (Connecting, Organizing, Reflecting, Extending) on improving student problem solving abilities and expected interaction between students in discussing solving problems, and making it easier for students to understand the material being taught.

The expansion of knowledge can be done by using the concepts that have been obtained into new situations or different contexts as the application of the concepts learned, both from one concept to another concept, other fields of science, and into everyday life. In discussion activities, students are expected to be able to expand their knowledge by working on questions related to the concepts learned but in new situations or different contexts in groups.

\section{Conclusions}

Based on the explanation on this learning innovation report, it can be concluded that Learning innovations in Bank and Financial Institution subjects with CORE learning models produced by Learning Plan, Teaching Materials, Media and Learning Videos. Learning innovations in Bank and Financial Institution subjects with CORE learning models can improve communication skills, think critically and innovatively students. Learning innovations of Bank and Financial Institution Course with CORE learning models are expected to strengthen the competitiveness of Economics Faculty students in particular and Universitas Negeri Padang students in general to face the revolutionary era 4.0.

\section{References}

Calfee et al., Making Thingking Visible. National Science Education Standards, Riverside: University of California, 2004 h. 222.

Harris, J., H., \& L., G., Katz. (2001). Young investigators: The project approach in the early years. New York: Teachers College Press

Istarani. 2012. 58 Model Pembelajaran Inovatif. Medan: Media Persada.

J. D. Novak, Concept Maps: What the heck is this?, [online], http://cmap.ihmc.us/Publications/ResearchPapers/TheoryCmaps/TheoryUnderlyingConceptMaps. htm , Date 20 Oktober 2018.

John M. Echols dan Hassan Shadily, Kamus Inggris-Indonesia, Jakarta: PT Gramedia Pustaka Utama, 1976, h. 139.

Kasmir. 1999. Bank dan lembaga keuangan lain. Jakarta: Raja Grafindo.

Katz S. dan Nirula L., Portfolio Exchange,

http://www2.sa.unibo.it/seminari/Papers/2009070720Criscuolo.doc, accessed date 20 oktober 2018.

Martalena dan Maya malinda. 2011. Pengantar pasar modal . Yogyakarta: Andi offset 
Muhammad Fathurrohman. 2015. Paradigma Pembelajaran Kurikulum 2013 Strategi Alternatif Pembelajaran di Era Global. Surakarta: Other.

Mulyani Sumantri dan Johar Permana, Strategi Belajar Mengajar, Depdikbud, 1999, h. 42.

Ratna Wilis Dahar, Teori-teori Belajar, Jakarta: Erlangga, 1989, h. 112.

Santi Yuniarti, Pengaruh Model CORE Berbasis Kontekstual Terhadap Kemampuan Pemahaman Matematik Siswa, Jurnal PRODI PMT STKIP Siliwangi Bandung: Tidak diterbitkan, 2013, h. 3.

Siamat, dahlan. 1995. Manajemen lembaga keuangan. Jakarta: Intermedia.

Silberman, Melvin L. 2007. Active Learning 101 Cara Belajar Siswa Aktif. Bandung: Nuansa. Sugiyono.2010. MetodePenelitian Kuantitatif Kualitatif \& RND. Bandung : Alfabeta

Suharso dan Ana Retnoningsih, Kamus Besar Bahasa Indonesia Edisi Lux, Semarang: CV. Widya Karya, 2009, h. 324.

Suyatno, Menjelajah Pembelajaran Inovatif, Sidoarjo: Masmedia Buana Pustaka, 2009, h. 67.

Syaiful Sagala, Konsep dan Makna Pembelajaran, Bandung: Alfabeta, 2007, h. 91.

Tandelilin, Eduardus. 2010. Portofolio dan investasi teori dan aplikasi. Yogyakarta: kanicius

Yuwana Siwi Wiwaha Putra, Keefektifan Pembelajaran CORE Berbantuan CABRI Terhadap Motivasi dan Hasil Belajar Peserta Didik Materi Dimensi Tiga, (Skripsi FPMIPA UNNES Semarang: Tidak diterbitkan, 2013), h. 6. 